Tourism in Brazil: from politics, social inequality, corruption and violence towards the 2030 Brazilian tourism agenda

\title{
Gui Lohmann
}

Griffith University, Australia

g.lohmann@griffith.edu.au

Heros Augusto Santos Lobo

Federal University of São Carlos, Brazil heroslobo@hotmail.com

Luiz Gonzaga Godoi Trigo

Universidade de São Paulo, Brazil trigo@usp.br

Vander Valduga

Federal University of Paraná, Brazil vandervalduga@gmail.com

Rafael Castro

CEFET/RJ, Petrópolis, Brazil rafael.teixeira@cefet-rj.br

Mariana de Freitas Coelho

Federal University of Viçosa, Brazil marifcoelho@gmail.com

Marina Wöhlke Cyrillo

Instituto Federal de Educação, Ciência e Tecnologia do Rio Grande do Sul

Marina.cyrillo@poa.ifrs.edu.br

Yoná Dalonso

University of the Region of Joinville, Brazil yona.dalonso@univille.br

Maria Henriqueta Gimenes-Minasse

Universidade Anhembi Morumbi mariegimenes@gmail.com

Marlusa de Sevilha Gosling

Federal University of Minas Gerais, Brazil mg.ufmg@gmail.com

Ricardo Lanzarini

Federal University of Rio Grande do Norte, Brazil ricardolanzarini@ccsa.ufrn.br

Sergio Rodrigues Leal

Federal University of Pernambuco, Brazil sergio.rleal@ufpe.br

Osiris Marques

Federal Fluminense University, Rio de Janeiro, Brazil 
osirismarques@id.uff.br

Verônica Feder Mayer

Federal Fluminense University, Rio de Janeiro, Brazil

veronicamayer@id.uff.br

Jasmine Cardozo Moreira

Ponta Grossa State University, Brazil

jasmine@,uepg.br

Lauro Almeida de Moraes

Federal University of Paraná, Brazil

lauromoraes@ufpr.br

Alexandre Panosso Netto

University of Sao Paulo, Brazil

panosso@usp.br

André Riani Costa Perinotto

Federal University of Piauí \& Ceará State University, Brazil

perinotto@ufpi.edu.br

Ambrozio Queiroz Neto

CEFET-RJ Uned Nova Friburgo, Brazil

ambrozio.neto@cefet-rj.br

Fabia Trentin

Federal Fluminense University, Brazil

ftrentin@id.uff.br

Sidnei Raimundo

University of São Paulo

sraimundo@usp.br 
Abstract:

Design/methodology/approach

This viewpoint paper is a combination of reflections by leading Brazilian tourism academics; most are members of ABRATUR, the International Academy for the Development of Tourism Research in Brazil. This paper uses secondary data from the grey (e.g., government reports) and academic literature to support this opinion paper. The tourism-related topics covered in this paper include economics, policy and planning, marketing, transport, nature-based tourism, gastronomy, hospitality, education, amongst others.

\section{Purpose}

Different from most academic publications about tourism in Brazil, this paper provides an overarching and comprehensive perspective. Analysing key developments, and focusing on the period 2000-2019, this paper also considers long-standing structural issues that hinder tourism development. Although this viewpoint paper deals with Brazil, very similar issues can be identified for many countries worldwide.

\section{Findings}

Brazil has missed several unique opportunities to place it as a destination of international renown. Since the 1990s, efforts to support regional tourism development have achieved only moderate success as political instability, violence and corruption have impacted tourism. A lack of a coordinated approach between the various levels of government, a shortage of tourism data, a longterm supra-government marketing campaign, among other factors, has meant Brazil has missed several critical opportunities in the 2010 s to establish itself as a leading tourism destination in the global market.

\section{Originality/value}

From leading tourism academic experts in Brazil, a unique opinion paper offers an overview of the critical development issues in 2000-2019. The paper presents matters that have hindered potential tourism contributions to the largest nation in South America. While these matters may be specific to Brazil, many of these challenges are not dissimilar to those in other emerging (democratic) nations. We offer several public policies and technical recommendations to scaffold tourism development towards the 2030 agenda.

Keywords: Brazil; tourism development; corruption; policymaking; planning; ABRATUR. 
设计/方法/途径

本篇观点论文是巴西前沿旅游学者们思考的集合, 其中大多数的学者是巴西旅游发展国际研究 院ABRATUR的成员。这篇论文使用了诸如政府工作报告的二手数据和学术文献来支撑文章观 点。其中涉及的与旅游相关的主题包括经济学, 政策和规划, 市场营销, 交通, 自然旅游, 烹 饪学, 酒店, 教育等等。

目的

与巴西大多数旅游研究的出版物不同, 本文提供了一个重要且全面的视角。文章重点分析了从 2000-2009年的旅游业主要发展状况, 同时考虑了阻碍旅游业发展的长期结构性问题。尽管此 观点论文涉及巴西，但在世界许多国家都可以发现非常相似的问题。

结果

巴西已经错失了作为国际知名旅游目的地的几个独特机会。二十世纪九十年代以来, 因为政治 动荡, 暴力和腐败对旅游业的影响, 支持区域旅游业发展的努力仅仅取得了有限的成功。各级 政府之间缺乏协调方式, 旅游数据短缺和长期的跨政府营销活动等因素, 已经意味着巴西在二 十一世纪前十年已经错失了将自己在全球市场中确立为领先旅游目的地的几个重要机会。

创意/价值

这篇来源于一些巴西学术旅游届的领头羊的独特观点论文概述了从 2000 年到2019年巴西旅游业 发展的关键问题。本文介绍了那些已经阻碍南美洲最大旅游国家潜在旅游业贡献的重要事项。 尽管这些事项可能是巴西独有的, 但是其中许多问题与其他新兴的（民主的）国家也没有什么 不同。我们提供了一些公共政策和技术建议，以支持旅游业向2030年议程迈进。 
Resumen:

Diseño / metodología / enfoque

Este artículo de opinión es una combinación de reflexiones de destacados académicos brasileños del turismo, la mayoría miembros de ABRATUR, la Academia Internacional para el Desarrollo de la Investigación en Turismo en Brasil. Se utilizan fuentes secundarias (por ejemplo, informes gubernamentales) y literatura académica para respaldar este artículo. Los temas relacionados con el turismo que se tratan en este documento incluyen economía, política y planificación, marketing, transporte, turismo basado en la naturaleza, gastronomía, hotelería, y educación, entre otros.

Propósito

A diferencia de la mayoría de las publicaciones académicas sobre el turismo en Brasil, este artículo ofrece una perspectiva global e integral. Al analizar los desarrollos clave y centrarse en 2000-2019, este documento también considera problemas estructurales de larga data que obstaculizan el desarrollo del turismo. Aunque este documento trata de Brasil, se pueden identificar problemas muy similares en muchos otros países del mundo. Resultados

Brasil ha perdido varias oportunidades únicas para colocarse como un destino de renombre internacional. Los esfuerzos realizados desde la década de 1990 para apoyar el desarrollo del turismo regional solo han logrado un éxito moderado debido a que la inestabilidad política, la violencia y la corrupción han impactado al turismo. La falta de un enfoque coordinado entre los distintos niveles de gobierno, la escasez de datos turísticos, una campaña de marketing supra gubernamental a largo plazo, entre otros factores, han significado que Brasil haya perdido varias oportunidades críticas en la década de 2010 para establecerse como un destino turístico líder en el mercado global.

Originalidad / valor

Un artículo de opinión único de destacados expertos académicos en turismo en Brasil, que ofrece por primera vez una visión general de los problemas críticos del desarrollo desde la década del 2000. El documento presenta asuntos que han obstaculizado las posibles contribuciones del turismo a la nación más grande de América del Sur. Si bien estos asuntos pueden ser específicos de Brasil, muchos de estos desafíos no son diferentes a los de otras naciones (democráticas) emergentes. Ofrecemos diversas recomendaciones técnicas y de políticas públicas para impulsar el desarrollo turístico hacia la agenda 2030. 


\section{Introduction}

This paper is a collective work by leading tourism academics who have expertise regarding tourism in Brazil and have published internationally. The majority of the authors are members of ABRATUR, the International Academy for the Development of Tourism Research in Brazil. In 2011, ABRATUR was founded by leading Brazilian and international academics with tourism expertise to contribute to the internationalisation of the tourism research in Brazil (www.abratur.org). The purpose of this viewpoint paper is twofold. First, due to the emerging nature of the international publications about tourism in Brazil, this paper offers an overview of the country as a tourism destination and highlights the critical issues that have hindered tourism development in the country. This paper offers a broad perspective rather adopting the fragmented approach usually presented in publications. Lohmann and Dredge (2012) offered the first book in English to provide a collective perspective of tourism in Brazil; since then, much has happened that needs to be considered. This paper offers the international scientific community an opportunity to better understand the challenges related to tourism in Brazil. After English, Portuguese is the second most published language globally in tourism studies. This paper allows a broader audience to become familiar with the progress of tourism in one of the world's largest countries. Second, from several perspectives, this viewpoint paper discusses the roadblocks faced in the field of tourism and proposes an agenda for the sector's improvement. While the views presented in this paper are specific to Brazil, several of the examined challenges are not dissimilar to those faced in other emerging (democratic) nations; thus, this review may help academics and practitioners gain a greater understanding of these critical challenges. The assessments presented in this paper should support leading stakeholders in Brazil, and eventually other countries, to have an honest reflection of the missed opportunities of the past, leading to the proposal of a 2030 agenda of transforming tourism for the benefit of their societies.

\section{Brazil as a tourism destination}

With its large population-based economy (comprising over 210 million people and the fourthlargest democracy in the world), Brazil has multiple levels of government (Valente et al., 2014) and significant territorial and economic inequalities. Historically, Brazil has been portrayed abroad as a libertine, lewd, and sensual country. This image is derived from the liberal sexual experiences that took place during colonial times when Europeans freely mingled with black people, first peoples, and enslaved people. Sérgio Buarque de Holanda's classic "Visão do Paraíso" (2010), which was originally published in 1959, constructs an idyllic, sensual, tropical image. This image is harmful to women and people with gender and sexuality identities outside of traditional Western heteronormativity (see Vizcaino-Suárez et al., 2019 for an analysis of 
gender in the context of tourism in Latin America). The image perpetuated by contemporary popular culture that depicted Brazil as a sexual paradise was strengthened by the tourism policies of the 1960s and 70s and by television dramas, movies, music, and mass events such as the Carnival. This imagery has had a direct impact on how the country was perceived and its appeal as a tourism destination.

Like many complex and large territorial countries, stereotypes of Brazil have been developed by mass media producers and local intellectuals or brasilianists, i.e., foreigners interested in researching Brazilian issues. As a result, simplistic and stereotypical concepts about Brazil flourished during the 20th century. These included ideas about sexuality, popular music (e.g., samba, bossa nova, funk, rap, and hip hop), the sympathy of the Brazilian people, the romanticized misery in favelas, the exuberant nature of Brazilians, and the "mess" or generalised disorder that was praised by historians (Minc, 1994). Some examples of this include the rascal sympathy expressed by Zé Carioca, a Disney character commissioned to strengthen Brazil's diplomatic ties with the United States during World War II. This character represents a soft power attempt to promote Brazilian culture (e.g., the movie "Alô, Amigos" from 1942) and a misinterpreted concept of the "cordial Brazilian" (Holanda, 2015). Sex symbols such as the actress Sonia Braga and the singer Carmen Miranda contributed, along with Carnival costumes, to the country's highly sexualized reputation, attracting sex tourism (Barreto \& Jensen, 2020).

As a diverse country, Brazil has poorly resolved historical issues, and it has experienced a very different reality from the imagery perpetuated throughout the 20th century. Although Brazil has a very diverse culture and many possible tourism destinations and attractions, the white sand beaches in Rio de Janeiro (Schallhorn, 2020) and the Amazon region are still foremost in foreigners' perceptions of the country (Mataruna-dos-Santos, 2020).

Because of its multi-ethnic cultural background, natural diversity and large geographical area, as well as the fact that the country has one of the largest economies in the world, Brazil has the potential to attract many tourism markets and segments (see Lohmann and Dredge, 2012 for further information). Many segments of Brazilian tourism hold large shares of the market, both in leisure and business tourism. Leisure tourism, which focuses on the sun and beach segment of the market, remains a prominent part of Brazil's tourism industry, particularly in coastline areas such as Rio de Janeiro, Santa Catarina, and the country's north-eastern states. This segment is supported by the ecotourism activities in the Amazon rainforest region (including those in the Amazon River) and in the Pantanal-Bonito axis in the central-west region. Cultural and historical tourism is preponderant in Minas Gerais and Bahia, with the state of São Paulo and the southern regions being renowned as gastronomic destinations. 
Several of the country's cultural and religious events are also popular, including the events related to New Year's Eve, the Carnival, Easter, and Festas Juninas (June's Celebrations) (see Figure 1).

Figure 1 Brazilian macro-regions, states and tourism destinations relevant to this paper

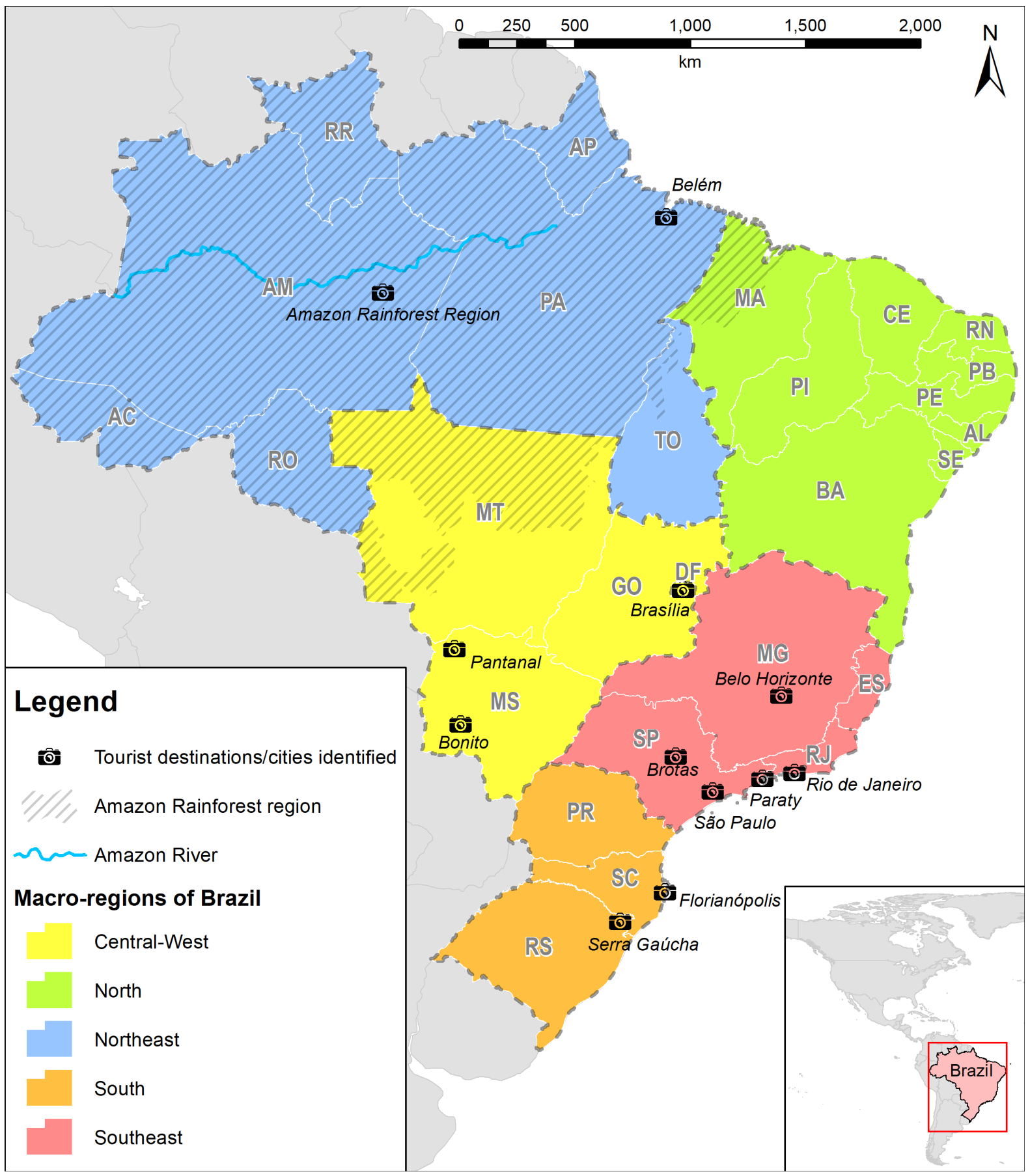

As is the case in other national economies, the tourism activities in Brazil are susceptible to the macroeconomic performance of the country. Since the 1990s, when Brazil entered another era of re-democratisation, attempts have been made to overcome problems in the industry. 
These endeavours include the development and consolidation of tourism as an economic and social activity. However, there is still a lack of tourism infrastructure that is reflected by various issues, including the need to reduce urban and long-distance mobility, improve levels of security, decrease crime rates, and improve the country's ability to attract internal and external investment (Trigo, 2003). The efforts that have been made in this regard are reflected in two key indicators, the industry's revenue generated and the total number of international arrivals (Figure 2). Despite its vast potential, the significant increase in tourism investment (by all levels of the government and the private sector), and the establishment of official targets to increase international demand, the country has had little success in attracting more than seven million international visitors per year (see Figure 2). Brazil has attracted five to six million international visitors per year since the mid-2000s. Even hosting sporting mega-events (i.e., the 2014 FIFA World Cup and the 2016 Olympic Games) has not significantly contributed to increasing international tourist demand (Marques et al., 2020) (Figure 2). This problem was further aggravated when the Real was devalued by nearly 50\% between May $2012(\mathrm{R} \$ 1.00=$ US\$0.50) and December $2016(R \$ 1.00=$ US $\$ 0.25)$, which should have favoured international visitors travelling to Brazil. Rabahy (2020) provides a comprehensive set of Brazilian tourism statistics for the period 2000-2018.

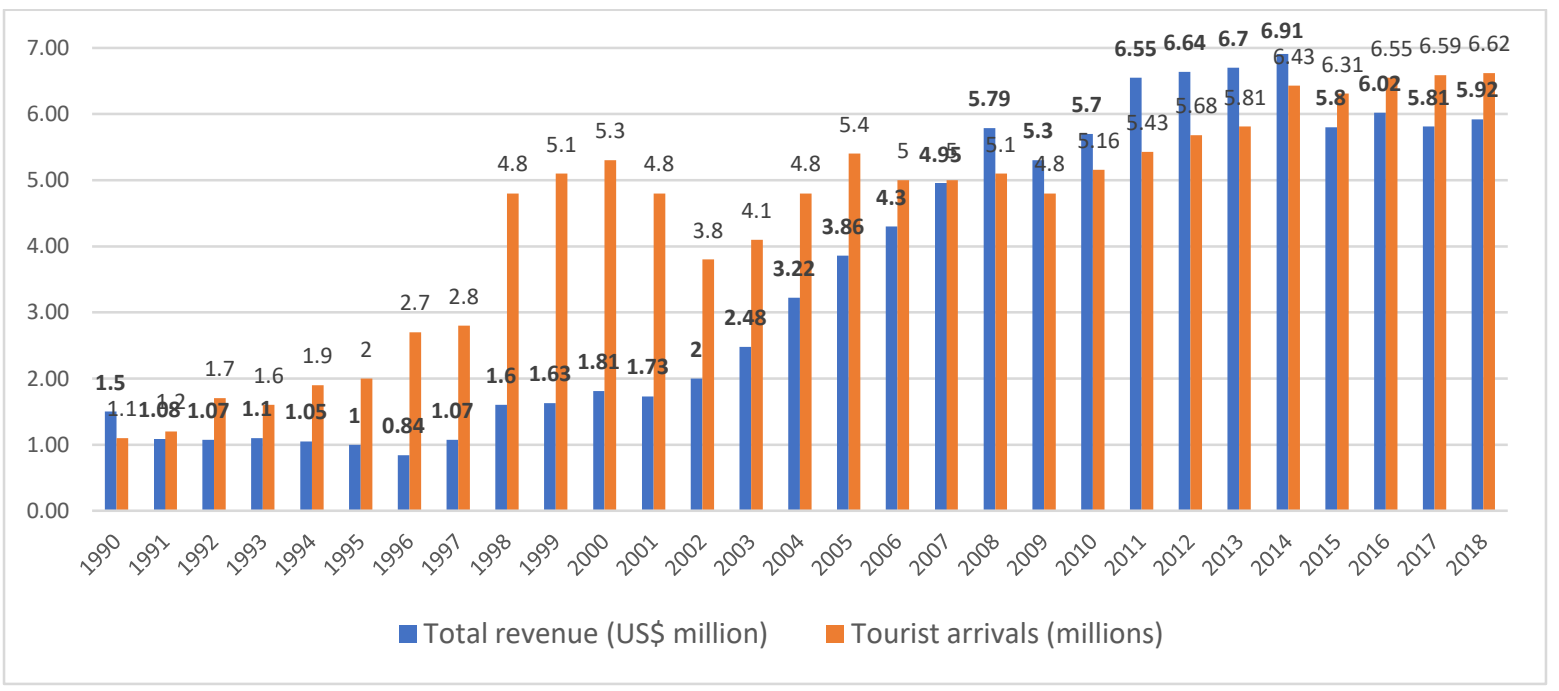

Figure 2 - International tourist arrivals and total revenue (1990-2018). Sources: Banco Central (2019) and Ministério do Turismo (2019)

The growth in events and business tourism in Brazil is the result of a well-targeted policy to support this segment, particularly through the strong participation of the private sector and the Conventions \& Visitors Bureaux (C\&VB). Since 2003, Embratur (the Brazilian Tourism 
Institute) started supporting C\&VB in its efforts to attract international MICE (Meetings, Incentives, Conferences and Exhibitions) and promote national MICE. MICE, and the logistic providers that support these activities, represent approximately $4.6 \%$ of Brazil's GDP, and this sector generates 25 million formal jobs (Ministério do Turismo, 2019b). Additionally, data show that during the first half of 2019 , business travel in Brazil increased $14.7 \%$ over the same period in the previous year. In 2018, business tourism was the second most popular reason for foreign travel, accounting for $13.5 \%$ of all the country's visitors. The average daily per capita spending of business travellers amounted to \$84.33. According to Ubrafe (2019), Brazil is the most popular Latin American destination for congresses and corporate events. Worldwide, Brazil is ranked the $17^{\text {th }}$ most sought-after destination by executives involved in MICE. São Paulo, Rio de Janeiro, and Foz do Iguaçu are the most desirable destinations for this segment (ICCA, 2019).

Since 2007, Brazil has become more competitive, climbing 32 ranks in the Travel and Tourism Competitiveness global rankings (Table 1). This was the consequence of what the World Bank (2015) calls the "Golden Decade (2003-2013)" and of the additional investments made in the infrastructure associated with hosting and organising major sporting events. In the various editions of the World Economic Forum's Travel and Tourism Competitiveness Report, Brazil has been recognised for its natural resources, obtaining a higher score than any other country. However, Brazil's business environment deserves a negative score, as its competitiveness attributes related to this issue have remained weak.

Table 1 - Brazil's T\&T Competitiveness Ranking Position and International Visitors' Arrivals in Brazil (2007-2017)

\begin{tabular}{|c|c|c|c|c|c|c|c|c|c|c|c|c|}
\hline & 용 & 유 & 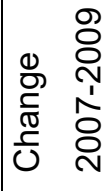 & $\underset{\check{N}}{\check{N}}$ & 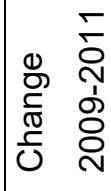 & $\stackrel{m}{\grave{n}}$ & 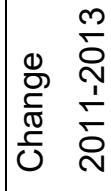 & $\frac{n}{2}$ & 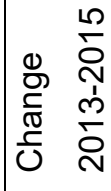 & $\frac{N}{\grave{2}}$ & 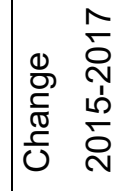 & 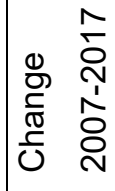 \\
\hline $\begin{array}{l}\text { T\&T } \\
\text { Competitiven } \\
\text { ess position }\end{array}$ & 59 & 45 & +14 & 50 & -5 & 51 & -1 & 28 & +23 & 27 & +1 & +32 \\
\hline $\begin{array}{l}\text { International } \\
\text { visitors' } \\
\text { arrivals (000) }\end{array}$ & 5,026 & 4,802 & $-4 \%$ & 5,433 & $13 \%$ & 5,813 & $7 \%$ & 6,306 & $8 \%$ & 6,589 & $4 \%$ & $31 \%$ \\
\hline
\end{tabular}


Source: The Travel and Tourism Competitiveness Reports, 2007; 2009; 2011; 2013; 2015; $2017 ; 2019$

\section{Social inequality, corruption, and violence: Structural issues that hinder tourism development}

Economic scholars continually analyse the association between corruption and lower levels of economic development, as corruption is one of the structural factors that hinders the growth of emerging economies. In Brazil, it also contributes to persistent and entrenched socioeconomic inequality. In the latest Corruption Perceptions Index (CPI) released by the NGO Transparência Internacional (2019), Brazil ranks $105^{\text {th }}$ out of 180 countries and territories. The country's tourism portfolio has become important leverage for bargaining between the legislative and executive powers. In the country's 2013 budget, the resources channelled to the Ministry of Tourism via legislative amendments reached a value of nearly $\mathrm{R} \$ 2$ billion. Most of these funds were used to finance events at the local council level, which is the electoral base of the members of parliament (MPs). The intangibility of services, such as that of performing arts and sound services, enabled them to be overpriced. Those involved in this overpricing and in the rigging of bidding processes were accused of corruption by the federal prosecutor. One of the investigations indicated that an MP charged bribes ranging from $10 \%$ to $12 \%$ of the funds released through a legislative amendment to arrange local events for organisers. Several studies have highlighted the active participation of the private and third sectors in corruption (e.g., Gomes, 2012). According to Lima et al. (2016), Santos et al. (2019) and Marques et al. (2020), both the 2014 FIFA World Cup and the 2016 Olympic Games in Rio de Janeiro exhibited evidence of corruption (Bondarik et al., 2020). In preparation for the Olympic Games, investigations were conducted that uncovered corruption cases across all levels of the government. As a result, the social and economic benefits generated by these events were far less than expected by society and businesses; indeed, this outcome was attributed to a lack of adequate planning and to systematic corruption.

A long coexistence of the police officers of the old death squads of the 1960s related to the dictatorial military regime (1964-1985) and the collusion between the leaders of the clandestine game (Jogo do Bicho) forged a spurious and corrupted alliance between the police and bandits. The mixture of police, military violence and crime formed a clandestine network of paramilitary violence that created the current militia models, especially those in Rio de Janeiro. Likewise, the coexistence of ordinary prisoners and political prisoners allowed organised crime groups to form tactical and strategic organisations. (Manso, 2020, p., 139). 
As a result, Brazil has a systematic violence problem, particularly in its largest state capitals, with an average of 50.4 homicides per 100,000 inhabitants annually (de Miranda Mota et al., in press).

In addition to these law-and-order issues linked to corruption, the country's profound divisions in terms of class, power, responsibility, and duty, as well as the high concentration of income, wealth, property, and privilege held by a few individuals, have led to social inequality and violence. The lack of urban dwellings and poor public transport access have facilitated the growth of favelas in the peripheries of Brazil's capital cities, which have been famously depicted in the hills of Rio de Janeiro. The cultural valorisation of Brazilian favelas, in connection with tourism investments (Angelini, 2020), has resulted in what is called favela tourism. However, this tourism segment quickly proved to be unsustainable, as "this spectacularizing made the favelas both a commodity for the tourist gaze and a warzone for arbitrary killings" (Freire-Medeiros et al., 2020, p.1).

The moralistic and repressive thinking that is expressed in machismo, homophobia, and racism persists in Brazil, and it has led to violence against minority groups, such as black communities, women, and the LGBTI+ community. Data from the Atlas of Violence (IPEA, 2019) show a daily average of 13 femicides. Most of these victims are black, poor women who live in the north-east macro-region of Brazil, an area profoundly marked by macho culture and colonialism. According to Forbes (2019), Brazil is the second most dangerous country in the world for women travelling alone. These issues impact not only the Brazilian population but also the international image of the country, as they portray Brazil as a dangerous destination.

\section{Economy and distribution of wealth}

Brazil has the fifth largest population, as well as the fifth largest territorial area, in the world, and it has enormous proportions and the world's ninth largest economy. Despite this, the average annual income per capita is only US $\$ 9,126.90$, placing Brazil 75 th in the world in this regard (2018). The country is also socially unequal, as it had a Gini index of 0.515 in 2016 , making Brazil the 10th most unequal country in the world. Services account for $73 \%$ of the country's GDP (IBGE, 2016), indicating that the Brazilian economy is predominantly focused on the domestic market. Brazil is also one of the most closed economies in the world, as international trade represents less than $30 \%$ of its GDP while the world average is approximately $85 \%$ (IMF, 2019). In Brazil, the number of domestic tourists is more than 30 times that of international travellers (Ministério do Turismo, 2019a). Travel and tourism represent $7.7 \%$ of Brazil's GDP, while other countries, such as Mexico (15.5\%), Turkey 
(11.3\%), Australia (10.8\%), Saudi Arabia (9.5\%) and the US (8.6\%), have higher levels of participation (Visual Capitalist, 2020).

A significant period of international tourism growth occurred shortly after the country stabilised its economy and controlled the existing hyperinflation, and this period was promoted by the "Real Plan/Plano Real" of 1994. The financial crisis that began in 2014 has been reflected in the sector. According to data from the Ministério do Turismo (2019a), the number of international tourists increased slightly between 2014 and 2018, namely, from 6.4 million to 6.6 million. Though this was a time of significant growth in global tourism demand, Brazil was unable to take advantage of the trend, and the country exhibited growth well below the world average (7\%) and America's average (4.8\%) in 2017 (WTTC, 2018). The unstable political climate, which started with the street demonstrations in mid-2013 and evolved into political dissatisfaction and the manoeuvre that produced the presidential impeachment in 2016, deepened the ongoing economic crisis. The federal government was paralysed, and several state companies (e.g., the state-run energy firm Petrobras, which is Brazil's largest corporation and one of the largest corporations globally) were unable to establish new business deals. As a result, the unemployment rate increased during this five-year period (2015-2019), and the rates during these years were $8.43 \%$ (2015), $11.60 \%$ (2016), $12.82 \%$ (2017), $12.30 \%$ (2018), and $11.9 \%$ (2019).

The tourism sector also saw a decrease in its leisure and business markets. The accommodation sector was particularly impacted by the political and economic crisis. After three consecutive years of decline in turnover, in 2018, the overall performance of the hotels in Brazil increased by $4.7 \%$ in terms of RevPAR (revenue per available room). A study by JLL's Hotels \& Hospitality Group (2019) showed a slight economic recovery, with a 4.1\% increase in the average occupancy rate, going from $56.5 \%$ in 2017 to $58.9 \%$ in 2018 . This growth, which was minor compared to related global statistics, was mainly due to the impact of the business and events segment of the tourism industry, which represented approximately $75 \%$ of the demand in 2018 .

From the perspective of supply, chronic problems have been caused by the complexity of legislation, economic and legal uncertainty, excessive bureaucracy, and a vast and complicated taxation system that encompasses various taxes and tax rules. A lack of incentives to start new businesses and high interest rates harms the competitiveness of Brazilian companies. Within the tourism industry, there is an overall lack of coordination among the various involved organizations, leading to low returns for investors who offer nonintegrated, value-added tourism products. 
The current poor understanding of the contribution of tourism to the Brazilian economy is exacerbated by a lack of specific, transparent, and timely tourism data (Santos, 2017). Tourism is not recognised in the "National Accounts System/Sistema de Contas Nacionais" (SCN) and its characteristics are not regularly measured along with other national and state statistics. The absence of a Tourism Satellite Account suggests that tourism as a sector is yet to be structured. This is reflected by the difficulty faced in estimating the direct contribution of tourism to the country's GDP. These factors impact critical decision-making processes in both the public and private sectors.

Targeted strategies such as investing in infrastructure to support major sporting events and establishing new policies that eliminate the visa requirements for leading international markets have made some progress. Despite the private sector's role in driving several enterprises, the government controls large parts of the economy, and there are high costs involved in operating businesses in the sector and the broader economy. The business environment needs to be improved by fostering entrepreneurship and innovation, reducing and simplifying tax burdens, and reducing bureaucracy. Brazil, like the other countries that have experienced rapid growth in tourism, must address a history of discontinuity in its tourism policy and implement tourismspecific economic monitoring instruments.

\section{Politics, policy and planning}

Since the 1990s, Brazil's tourism-related policies and plans have been developed in a decentralised manner, and social participation in the formulation and implementation of policies has been encouraged. Critical to this process was the "National Tourism Municipalisation Programme/Programa Nacional de Municipalização do Turismo" (PNMT), which was launched in 1993. Within this sizeable territorial country structured over three levels of government, namely, the national/federal, state ( 26 states and one federal district), and local (5,570 municipalities) levels, the PNMT identified several local destinations with tourism potential. The PNMT addressed tourism infrastructure, products, and promotion. As a result, new destinations emerged, including some occupying niche markets that offered nature-based and adventure activities, such as Bonito and Brotas (Carnicelli-Filho and Lohmann, 2012). The PNMT also contributed to the creation of the "Municipal Tourism Councils/Conselhos Municipais de Turismo" (Comtur), bringing together and encouraging public and non-public actors to participate in tourism policy and planning at the local level (Araujo and Dredge, 2012).

The National Tourism Policy (1996-1999), through its operational instruments (e.g., the "National Tourism Plan/Plano Nacional de Turismo" - PNT), proposes an increase in the number of international tourists, their length of stay, and the revenue generated by foreign 
visitors. The Ministry of Tourism has developed strategies proposing the establishment of regional governance bodies capable of devising tourism products and promotion across the different macro-regions of Brazil. PNT established training opportunities for public managers to overcome local and regional deficiencies and has provided financial support for tourismrelated facilities and projects. Additionally, private involvement has occurred through the engagement of local tourism businesses.

In 2004, the "Tourism Regionalisation Programme/Programa de Regionalização do Turismo" (PRT) was adopted. The PRT was innovative in its regional approach to tourism, proposing the institutionalisation of regional governance bodies and seeking to engage public and private stakeholders in collaborative opportunities (Trentin, 2016). The 2003-2007 PRT (2004), which was established through the Integrated Itineraries Programme, aimed to increase the quality of tourism products (Valente et al., 2015) and to implement at least three high-quality tourist attractions or products in each state (Ministério do Turismo, 2003). As a result, the regionalisation process was restructured and adapted to boost tourism at the regional level. This process was achieved by establishing and strengthening tourism as a transformative economic and social agent. Although the purpose of the regionalisation process was to increase and diversify integrated travel itineraries and to improve the overall quality of the supply and competitiveness of tourism (1998-2018), the strategy failed to significantly increase the number of international visitors. The regionalisation process had a major impact on the domestic market, including on the region of "Hortênsias" and the "Grape and Wine Region" in the Serra Gaúcha of southern Brazil (Ministério do Turismo, 2018a).

\section{Branding, image, marketing and promotion - offline and online}

Brazilian international marketing and promotion have historically depended on Embratur, which was launched in 1966. For several decades, particularly in the 1980s and 1990s, Brazil's international image and promotional material emphasised the appeal of sun, sex, soccer, and samba dancing. The Carnivals, the sensuality of Brazilian women, and the pristine beaches still capture the imagination of many potential tourists (Bandyopadhyay and Nascimento, 2010). In the 2010s, there was an attempt to diversify this image; during this time, Brazil successfully secured two major sporting events, the 2014 FIFA World Cup and the 2016 Summer Olympic Games in Rio de Janeiro. While both of these events helped to increase tourists' intentions to travel to Brazil (Schallhorn, 2020), they failed to achieve significant growth in terms of international tourist numbers and revenue (Mataruna-dos-Santos, 2020) (see Figure 2). 
Since 2003, the overseas promotion of Brazil has been influenced by the guidelines proposed by the "Aquarela Plan/Plano Aquarela", which identifies the products linked to each macroregion of the country. Supporting the Aquarela Plan structurally changed the way that new products were prepared for the international market. This change included the establishment of packages and itineraries that lasted seven, 14, or 21 days, with the option of segmented packages and itineraries (e.g., sun and sea, ecotourism and adventure, cultural, sporting, business, event and convention packages). A successful aspect of the Aquarela Plan was its proposition of guidelines intended to promote Brazil internationally, which reinforced the need to update and improve the country's image to achieve long-term results. One of the challenges faced in establishing and promoting a brand for Brazil is the country's diverse culture, which is historically mixed and comprises Brazil's indigenous people, the decedents of the African slave trade, and European colonisers. Although the country is united by one language, Portuguese, its cultural diversity was evoked in a recognised Brazilian brand logo, the "Marca Brasil", which is a colourful icon with four overlapping irregular shapes. The federal government discontinued the use of this logo in 2019, and it was replaced by a logo with the Brazilian flag and the words "Brazil, visit and love us". This new slogan is controversial, as some tourism stakeholders and specialists viewed it as a reinforcement of the sexualization of Brazilian women.

Perinotto et al. (2020) evaluated the official Brazilian tourism website from the perspective of Kotler's seven Cs in the field of digital marketing. From their results, they concluded that concerning interactivity, communication and digital marketing, Brazil's official tourism website was underutilised; indeed, its use was equivalent to that of a digital electronic folder. Through their analysis, they found a lack of interactive resources; users did not have an opportunity to provide feedback, and communication was limited and unidirectional. The official tourism website failed to meet the basic requirements for such a tool by not providing content in the native languages of users whose countries have direct flights to Brazil. In addition, there is a lack of engagement within the official Brazilian tourism social media channels, and these channels do not feature photographic images of the iconic tourist attractions in Brazil. However, it seems that investing in digital marketing should be a priority for Brazil's tourism promotion in the near future.

\section{Gastronomy}

Brazil has excellent gastronomic diversity as a result of its geographical conditions, its multiethnic, mixed inhabitants, and its immigrant population. The unique ingredients and diverse culinary traditions within the country have created different flavours and confer a regional identity on Brazilian food. However, there are challenges involved with becoming competitive 
in this tourism sector. These challenges include the difficulties faced in developing regional tourism products, which are a result of the poor coordination between entrepreneurs and public-private partnerships. There is also a lack of visibility for gastronomic attractions in the context of tourism promotion (Mascarenhas and Gândara, 2015). Although the country is highly competitive from a cultural perspective, other aspects of culture, such as dance, are emphasised in marketing campaigns. The circulation of culinary staples (such as olive oil, cheese, and wine) is also limited by state laws and logistics, reducing the access of restaurants, chefs, and end consumers to genuinely Brazilian flavours (Braga and Bercovici, 2018). There is also a shortage of managerial and operational labour training, which is underdeveloped outside major urban centres. Within the leading schools and universities of the country, the principles of international cuisine are emphasised over Brazilian specialities, and very few courses are related to gastronomy, particularly at the postgraduate level.

The situation of Brazilian gastronomy points to the development of geographical indications (GI) and designations of origin (OD). Movements such as that of slow food are expanding across the largest regions of Brazil, and alternative food networks are growing, such as those involving organic, ecological, agroecological, biodynamic, natural, regenerative, biological and permaculture foods (Darolt et al., 2016). As a result, Brazil is maturing and attracting sophisticated food travellers, and gastronomy is supporting the overall tourism experience of the rich Brazilian culinary culture. The inclusion of Belém, Florianópolis, and Paraty in the gastronomy category of UNESCO's Creative Cities Network creates opportunities for other gastronomic regions in the country. Other destinations, such as Belo Horizonte (MG), have also been recognised for their excellence in the provision of gastronomic experiences.

\section{Air transport and accessibility}

The 1990s brought structural change to the Brazilian air transport sector, including a liberalisation of economic regulations. In the early 2000s, these changes facilitated the arrival of new airline business models, such as those of the low-cost carriers Gol Airlines (2001) and Azul Airlines (2008) (Lohmann et al., 2013). ABEAR (n.d.) estimated that there was a 70\% drop in airfare prices since the 2000s, suggesting that the liberalisation adopted was a decisive factor in reducing tariffs. Moreover, deregulation has continued in terms of foreign airline ownership. While this environment has improved the supply and competition on the trunk routes, particularly those linking state capital cities and major urban centres, regional access is still expensive and, in most cases, poorly serviced (Oliveira et al, 2020).

A federally owned company (Infraero) began conceding some of the largest airports in Brazil to private operators (mostly international ones) in 2012; these airports were transferred in lots, 
starting with those located in large capital cities. A performance analysis of the first stage of this privatisation did not reveal significant managerial improvement (Fernandes and Pacheco, 2018). Several of these airports managed by private operators were unable to reach the expected levels of passenger demand. These airports were unable to meet their financial obligation to pay for their government concession; thus, they were in danger of being returned to the public sector, and doubts were raised as to the sustainability of the concession/privatisation model (Marques et al., 2019). In addition to being overpriced, the proposed concession model required several adjustments at various phases, emphasising its inadequacy in comparison with the airport privatisation models used in other countries. Most airports, especially those operated by private companies, were modernised during the 2010s to help accommodate major sporting events. Despite the challenges created by this poorly implemented airport concession process, the country still experienced its best era in terms of airport infrastructure, both in the air and land sides. Studies suggest that an increase in passenger comfort, including improved seating capacity and a wide variety of shopping and food and beverage retailers, increased the frequency of flights to Brazil and led to the establishment of hubs outside the Rio de Janeiro and the São Paulo axes (Allis et al., 2017).

Figure 3 presents the passenger traffic of Brazilian airports from 1990 to 2018. After the 2001 9/11 terrorist attacks in the USA, Brazil experienced certain associated impacts from 200203. The following years were positive for the Brazilian economy, which became the sixth largest global economy measured by GDP in 2011. This prosperity enabled more air travel across the expansive country. In 2014, when Brazil hosted the FIFA World Cup, the country's passenger numbers increased by almost $7 \%$, as games were played in 12 different states. During 2015, this market continued to enjoy growth after the sporting event. However, these passenger numbers fell from almost 118 million to 109 million in 2016, which was the year of the Rio de Janeiro Olympic Games. This was caused mostly by the political and economic crisis (see other sections in this paper) that occurred, emphasising that Brazil's political and economic instability held the country back despite this once in a lifetime opportunity to take advantage of a major sporting event to rebrand the country as a global tourism destination.

Figure 3 - Number of airline passengers, in millions (1990-2018) 


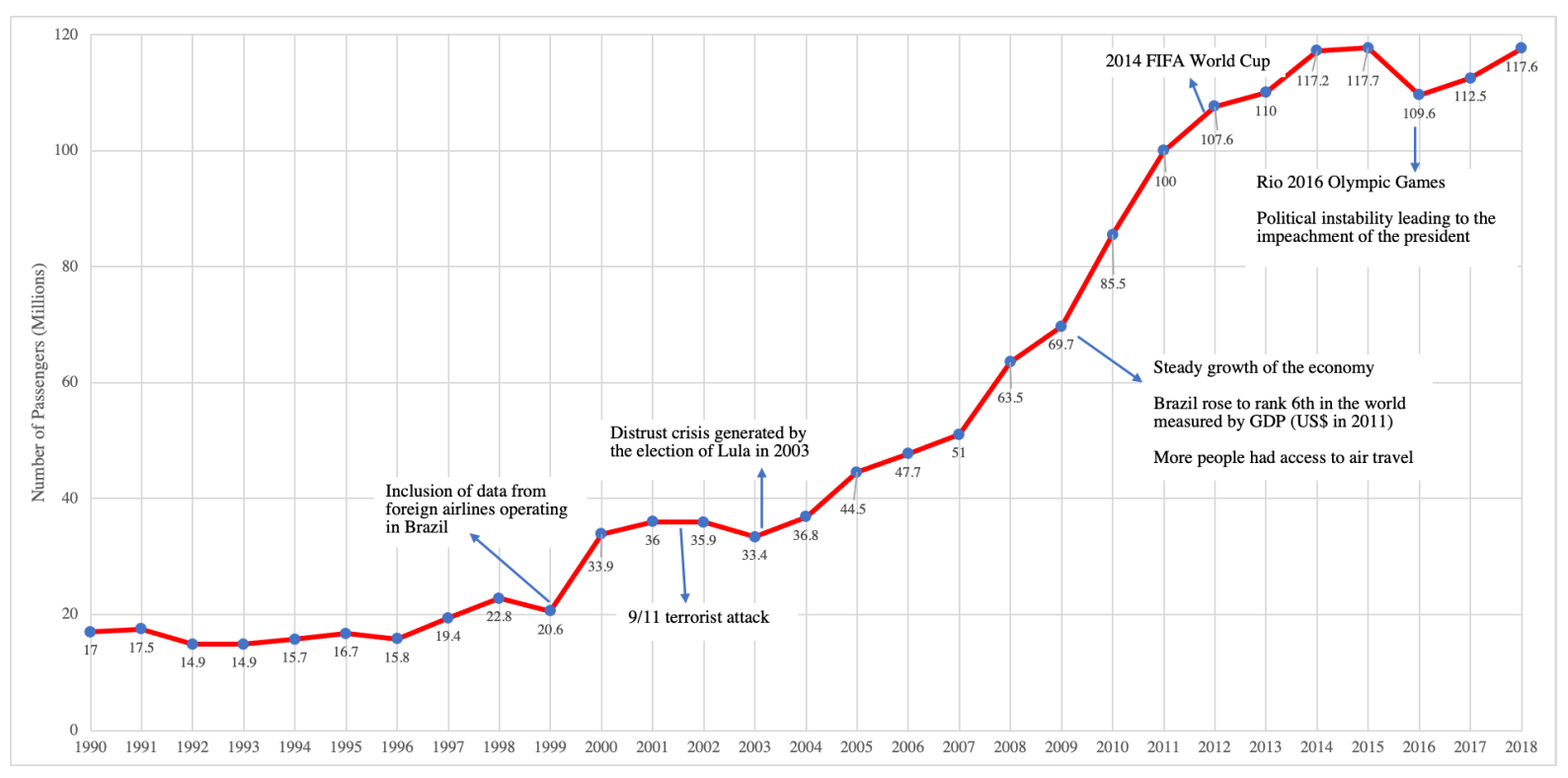

\section{Cruise tourism}

The cruise industry is another tourism transport sector that has undergone a significant transformation. Since the 1990s, the absence of cabotage rights (1998) has allowed international cruise lines to operate along the Brazilian coast; consequently, this sector has expanded. The change in regulation required that at least $30 \%$ of a ship's crew was composed of Brazilians, and it was seen as a way to foster social benefits (Lohmann et al., 2013).

Figure 4 illustrates the increase in passenger numbers that began during the mid-2000s as a result of these regulatory changes and as cruises began attracting Brazilian and international tourists. The summer cruise season in Brazil usually starts around mid-November and ends in March/April of the following year. Then, the cruise ships relocate to the Northern Hemisphere for the slower winter season. From comprising only six ships and 139,000 passengers in the 2004/2005 season, this sector grew to feature 20 ships by 2010/2011 and 805,000 passengers by $2011 / 2012$. From the $2011 / 2012$ season onwards, the number of vessels and, consequently, the number of passengers began to decrease, mainly due to the high costs incurred in Brazilian ports. Even though the number of ships remained the same $(n=7)$, in 2017/2018, the passenger numbers began to increase again, albeit slowly. This increase is demonstrated in the industry's number of bed nights, as shipowners bring larger ships to Brazil every year. In 2019/2020, the number of bed nights increased by $6.3 \%$ to over 500,000 (CLIA Brasil, 2019).

Despite the increase in passenger numbers that occurred from the middle of the 2000s until the early 2010s, several factors have limited the development of the cruise industry in Brazil 
(CLIA Brasil/FGV, 2018). These include the non-competitive nature of port charges and a lack of proper berthing and terminal infrastructure.

Figure 4 - Number of passengers (000s) and cruise ships on the Brazilian coast per season (2004-2019)

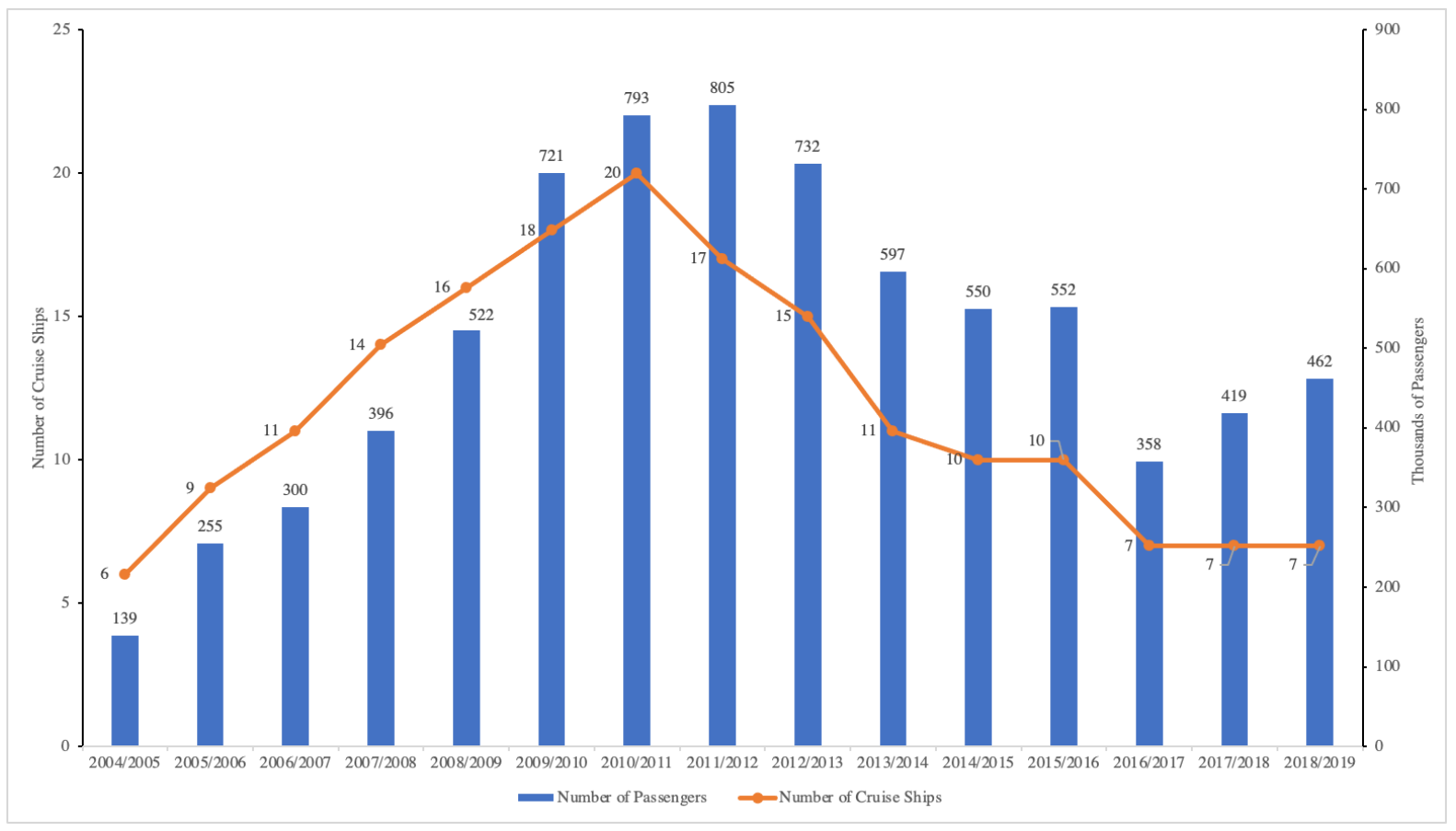

\section{Parks and conservation areas}

In Brazil, there are several types of protected areas, permanent protection areas, legal reserves, listed heritage sites, indigenous and quilombola territories, and Conservation Units/Unidades de Conservação (UCs). Tourism is focused in the areas established by the "National System of Conservation Units/Sistema Nacional de Unidades de Conservação" (SNUC) legislation. The SNUC divides these natural protected areas (PAs) into two groups: full protection areas and sustainable use areas. Full protection prevents the direct use of natural resources, and these areas are restricted to uses involving the contemplation of nature through educational practices, environmental experience, and research. Ecotourism is the predominant socioeconomic activity in these areas. Sustainable use regulations aim to ensure that the principles of nature conservation are compatible with the direct, sustainable use of an area's natural resources. The tourism development in these areas includes ecotourism, but other forms of tourism are also allowed due to a greater level of flexibility in the areas of designation that allows for anthropic use. PAs are governed by specific rules and guidelines provided for within their management plans or equivalent documents. There are currently 2,309 PAs in Brazil, which encompass approximately 250 million hectares, account for almost 
$19 \%$ of the land area, and cover $27 \%$ of the country's marine area (Ministério do Meio Ambiente, 2019). The studies by Souza et al. (2019) indicate that each dollar of government investment in the tourism infrastructure of protected areas produces seven dollars in economic benefits.

Certain areas that are known internationally also reconcile tourism with environmental conservation initiatives, such as World Heritage Sites (seven natural and one mixed), Ramsar Sites (27 areas), Biosphere Reserves (seven areas), and Geoparks (one area). Biosphere reserves have been included in the Brazilian legislation on protected areas, which makes their implementation more effective. For the World Heritage and Ramsar sites, as well as the geoparks, there is no legal provision that characterises them as protected natural areas. In all of these cases, in which Brazil is a signatory to international treaties, unique management and sustainable use proposals enable the development of various aspects of nature tourism, and recommendations are made for local and community development. This unique management style is relevant in the Brazilian context, given that many traditional communities live in or around these areas. When a debate concerning community-based tourism (CBTs) emerged in the 1990s, in which Brazil was a leader, several challenges were identified for the sustainable development of CBT enterprises (Lohmann and Dredge, 2012). These challenges are reflected across other regions and include issues related to market access, internal governance (Borrini-Feyerabend et al., 2013), and the management of strategic partnerships. As experienced in other developing countries, CBT enterprises have little chance of survival without external funds (Ngo et al., 2018, 2019).

It is understood that the number of visitors to protected areas and areas of international significance fall short of their potential. The advances of the 2010s have achieved little progress in terms of management proposals for tourism use, increased visitor volume, and the socioeconomic sustainability of protected areas. These areas are unable to meet their maintenance costs with the funds raised through visitation fees. As an example, in 2017, there were only 10.7 million visits to the UCs; in 2019 , there were 15.3 million visits to these areas (ICMBio, 2020). The ongoing actions undertaken by public managers to improve tourism in these areas may benefit from the creation of new products. The implementation of the National Trail Network and private initiatives with management partners offer some possibilities. These have been realized through the concession of public services related to tourist visitation to private enterprises. These initiatives diversify the industry's supply to attract new markets, improve visitor services, and generate local and indirect employment and income. Criticism concerning these concessions still exists among tourism practitioners due to the increased 
costs for visitors. Indeed, Brazil's leisure culture is already limited to a small proportion of its population, and this may further restrict the use of these natural areas.

With the reduction in international travel due to the COVID-19 pandemic, domestic tourism has emerged as an opportunity for Brazil due to its natural diversity and continental dimensions. As the leading country in the world in terms of the diversity of natural resources (Ministério do Turismo, 2018b), nature-based tourism is emerging as a promising driver of the economic and social recovery of Brazil's tourism sector. However, its success depends on a well-integrated and coordinated planning approach that has been neglected. The pandemic exposed the fragility of the communication between local stakeholders and government authorities in the context of nature-based destinations. Positive actions were taken in established destinations, such as the State Parks of Jalapão (Tocantins state) and Ibitipoca (Minas Gerais), the National Parks of Iguaçu (Paraná) and Fernando de Noronha (Pernambuco), and the regions of Bonito and Pantanal (Mato Grosso do Sul) and Vale do Ribeira (São Paulo). However, political and administrative divergences and a lack of broader guidelines reduced the positive impacts of these actions.

\section{Brazil tourism agenda for 2030}

Based on the historical trajectory and context of tourism in Brazil between 2000 and 2019, this paper provides recommendations for tourism in the 2030s based on the related international literature and concrete examples from professional experience (Table 2).

Table 2 Recommendations for the Brazilian 2030 tourism frontier

\begin{tabular}{|l|l|}
\hline Public policies & Technical aspects \\
\hline $\begin{array}{l}\text { To integrate tourism policies with other high- } \\
\text { level policies (e.g. educational, environmental, } \\
\text { transport) (Aall, 2015; Schiefelbusch et al., } \\
\text { 2007) }\end{array}$ & $\begin{array}{l}\text { To implement a Tourism Satellite Account } \\
\text { methodology (Pham et al., 2009; Jones et al., } \\
\text { To reduce the distance between tourism } \\
\text { To adopt key mechanisms to combat } \\
\text { corruption: prevention, } \quad \begin{array}{l}\text { academics and the private/public/NGOs } \\
\text { investigation, correction, and monitoring } \\
\text { (Brasil, 2016) }\end{array}\end{array}$ \\
$\begin{array}{l}\text { To reduce and simplify the taxation system } \\
\text { establishment of tourism observatories in each } \\
\text { state (Pan \& Yang, 2017) }\end{array}$ \\
(Vernon et al., 2005)
\end{tabular}




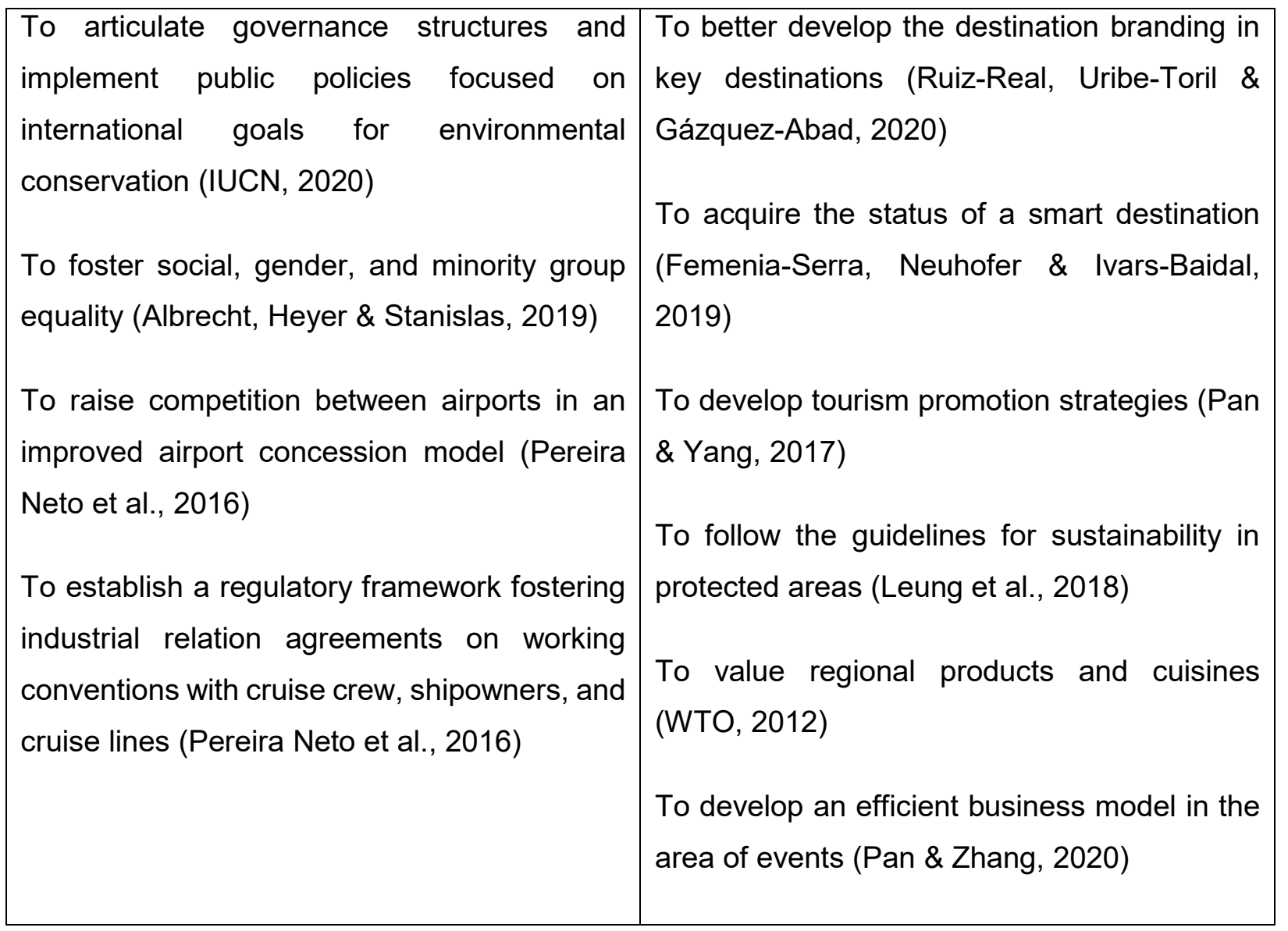

Many of the proposed recommendations go beyond the tourism sector, addressing aspects of Brazil's political and organisational environment. In this paper, the evident lack of political and managerial coordination in the country is highlighted. This gap is one of the factors that has facilitated the country's increase in corruption, which may be overcome by following the suggestions of the Brazilian Court of Auditors (Brasil, 2016). Operations such as "Lava Jato" are expected to be strengthened in the coming years, employing greater legal rigour in investigating and punishing corruption. The criminal accountability of private sector agents, which was implemented over a century ago in countries such as France, England, and Germany, will also contribute to future improvement in this sphere.

Political instability has resulted in a lack of reforms, particularly those aimed at reducing excessive taxation and bureaucratic legislation. As an example, a lack of stability is reflected in Brazil's inefficient conservation policies, which reduce the likelihood that the country will address its greenhouse gas emissions (Borrini-Feyerabend et al., 2013). Another unintended consequence of political instability is the continuation of social inequalities, including those impacting minorities of gender and sexual orientation and those involving barriers to social improvement. 
Work is also needed to improve the country's air and sea transport systems as well as its infrastructure that directly supports tourism. Redefined concession policies for airports may generate more competition and improve the overall quality of the services provided, resulting in price reductions. Within a 10-year time frame, Brazil could return its previously privatised airports back to government control, which would require additional rounds of concession. Additionally, actions should be taken to reduce the risks facing investors, including passing specific regulations concerning transactions with related parties, thoroughly reviewing the concession contracts that aim to rebalance economic and financial outputs, and implementing a consideration for indemnity in the case of the early termination of a concession (Machado et al., 2019). Progress for cruise tourism may be achieved through adjustments to the industrial relations policies that apply to shipowners, cruise lines, and crews; these should address a reduction in bureaucracy for overseas staff who need to obtain working visas (Adams, 2017). Port infrastructure investments, such as docking and passenger terminal facilities, are also required.

Specific tourism policies need to be based on an ongoing planning process. Policy changes should take place based on critical evaluations, not when a new government administration is elected. It is also essential to maintain the technical character of tourism agencies such as the Ministry of Tourism and Embratur to ensure that long-term policies and plans are focused on the sustainable development of the sector. One of the challenges in this regard is establishing models for vertical and horizontal coordination between public authorities, the private sector, and the third sector.

In addition to tourism-related policies, specific solutions are necessary to enable better performance in the sector. The establishment of CSTs to provide information for better decision-making in both the public and private sectors is critical (Pham et al., 2009; Jones et al., 2010). Tourist destinations need to be planned in accordance with social, organisational, environmental, and cultural attributes. The concept of smart destinations should be adopted, as these destinations have increased competitiveness (Femenia-Serra; Neuhofer; IvarsBaidal, 2019) and allow for improved managerial decision-making processes (Queiroz Neto et al., 2017).

The essential attributes of tourist infrastructure must be considered, such as employee training and trade qualifications based on customer experiences (Ruiz-Real et al., 2020) and tourism promotion strategies (brand creation, digital marketing, and traditional dissemination strategies) (Pan and Yang, 2017). The establishment of tourism observatories must be supported, as they foster tourism studies with the aim of better understanding the profiles of tourists and improving the current understanding of tourist behaviour (Pan and Yang, 2017). 
The same applies to monitoring the sentiments of tourists regarding a particular destination via social media, as was done in the case of Curitiba during the FIFA 2014 World Cup.

The cultural aspects of Brazil can be strategically employed to increase the attractiveness and uniqueness of tourist experiences. The integration of regional products and cuisines can foster authenticity and the promotion of well-being and health, which are associated with good tourist experiences (WTO, 2012). A conceptual example of this is the 'foodscape', which brings together local culture, creativity, and gastronomy (MacKendrick, 2014). Other best practices can also be adopted in parks and natural attractions. Guidelines for the sustainability of these areas could be provided in a best-practice concession framework, which could provide vital links between local communities, rural development, and conservation; aid in the reduction of adverse environmental impacts; lead to the empowerment of local traditional communities; and increase the overall level of environmental awareness through interpretation (Leung et al., 2018). Brazil needs to invest in natural protection and preservation, as this is a point of difference that enhances the image and travel experience of tourists. According to the World Economic Forum, the environment is one of the critical factors of Brazil's tourism competitiveness.

Finally, it is also necessary to think of events as promoters of Brazil as a destination. This can be achieved by developing a business model for events that is scalable, efficient, and profitable and by searching for digital solutions (Pan and Zhang, 2020).

Improving tourism in Brazil also depends on reducing the distance between the tourism industry and the private sector. Moving forward, the approach should focus on bilateral activities that solve issues by improving communications and increasing scholars' awareness of the tourism sector (Cai et al., 2017).

Education provides opportunities for problem solving in multisectoral activities such as tourism. Effective training assists in the development of intellectual and ethical foundations that enhance individuals' professional and citizenship skills (Trigo, 2020). In addition, there is a need to comprehensively consider the role of culture and education in representing Brazilian traditions and people in a more authentic way, forming a new generation of professionals to influence the media, shaping the arts, and recruiting online influencers to reduce the misconceptions and stereotypes associated with Brazilians worldwide (Barreto and Jensen, 2020).

The future is difficult to predict, but it is possible to prepare for different situations through dynamic and strategic planning. Addressing global issues such as the extreme concentration 
of wealth among a few individuals, the environmental and geopolitical issues creating refugees and poverty, and the exploitation of forests and ecosystems requires new approaches and collaboration. These approaches may help to reduce the predatory and selfish exploitation of natural and human resources. The cyclical crises of the 20th century highlight the web of issues that have challenged humanity but have been enhanced by advancements in information and communication technologies and supported by management, control, and governance processes. The only way to counterbalance this bureaucratic and centralising technocracy is to develop, in concert with the aforementioned advances, ethics, justice, the defence of individual freedoms, and the existence of a plurality of diverse cultures and lifestyles. Knowledge is central to the achievement of these goals and will be essential to guaranteeing the safety, equality, comfort, health, and pleasure of future generations. This is true for all sectors of society and the economy, especially for services targeting enjoyment, such as tourism. The critical training needs of tourism professionals from the 20th century remain relevant, but additional skills are required to face the new world (Trigo, 2020).

\section{Tourism as an enabler of a brighter future for Brazil}

The viewpoint of the authors of this paper provides an uncomfortable and exciting scenario of contrasts for tourism in Brazil. Brazil is a country of continental dimensions that is rich in diverse landscapes, natural resources, and cultural elements that offer countless opportunities to generate tourist interest. Since the 1970 s, when tourism higher education began to emerge, tourism has enjoyed national relevance due to its economic and social contributions. The current tourism education must be evaluated and questioned, as it has traditionally been based on a model that developed researchers rather than filling needs for skilled labour training. The fact that Brazil's primary language is Portuguese also causes a language barrier, as Brazil is located within a Spanish and English-speaking continent.

Tourism stakeholders must deal with the numerous problems, circumstances, and poor choices related to the underperforming tourism planning and management of Brazil, which have been exacerbated by the country's size. Issues posed by factors such as Brazil's distance from the major tourism markets and its vulnerability to political and economic instability hamper the development of tourism. In addition, successive structural and organisational misunderstandings in Brazil's tourism planning have highlighted the country's corruption, market failures, and government mismanagement and have done little to support the sector. 
Considering the topics covered in this viewpoint paper, it is clear that to increase the number of international visitors to Brazil, broader internal structural obstacles must be overcome, including the lack of institutional communication that has resulted in a fragmented approach to sectoral policies. The international market benefitted from the removal of the reciprocal visa requirements for citizens of the USA, Australia, Canada and Japan in 2019. Brazil's international advertising should seek to promote the outstanding cultural and natural elements of the country. Removing the traditional sexual and servile image of the Brazilian people, particularly that of minority groups, from the country's promotional material to elevate the natural and cultural richness of the country in eyes of the local and global community is critical for the advancement of tourism. Tourism may become a vehicle to highlight sustainability and human rights and combat child sexual exploitation and sex trafficking (Brooks and Heaslip, 2019). To achieve a more ethical outcome, strict laws will need to be enforced, and tourism stakeholders will need to take the lead in terms of the changes needed to support vulnerable populations and workers.

Brazil has been vulnerable to external crises, mainly due to a lack of planning and of the coordinated approaches required to deal with complex issues in such a large and underresourced democracy. While it is not the topic of this paper, the COVID-19 pandemic has exposed the country's political, social, and structural fragility. There have been difficulties in proposing effective strategies to control the virus. These include the lack of a social safety net allowing the population to follow lockdown requirements and the poor coordination between the national, state, and local governments. These factors have contributed to Brazil recording the second-highest number of COVID-19 deaths worldwide, as it has suffered over 186,356 casualties associated with the virus by December 2020 (WHO, 2020). As with the country's violence, Brazil has once more demonstrated the "banality of death" (Manso, 2020, p.24). Further evidence of government corruption and the inappropriate behaviour of citizens in response to the COVID-19 containment measures are examples of the country's lack of preparedness to deal with crises and the need for change imposed by new social dynamics. As a result of the pandemic, Brazil has made global headlines, and many countries no longer allow Brazilians to cross their borders, creating a sense of unease regarding potential future tourism. The economic effects of the COVID-19 pandemic will continue for many years into the 2020s.

The development of tourism within Brazil remains a complex issue, and past mistakes continue to overshadow the country's natural and cultural tourism potential (see Trigo, 2003). Tourism in Brazil could see improvement during the 2030s. However, to achieve this outcome, it will be necessary to increase the importance placed on tourism, and sufficiently support the 
industry with human, financial, environmental, and social resources; these issues exist in addition to those analysed in this paper. These outcomes will be particularly challenging as tourism recovers worldwide from the COVID-19 pandemic, with Brazil receiving negative attention from the global media due to the very high mortality rates across the country due to the virus. Due to the impact of the pandemic, the poor image of Brazil overseas and the political uncertainties that it will face moving forward, it is certain that the country will emerge from this crisis with other problems, stereotypes, and challenges. However, tourism still has the opportunity to bring economic, social and environmental development for a better future of Brazil and as academics and authors of this paper, we are committed to this cause.

\section{References}

Aall, C., Dodds, R., Sælensminde, I. and Brendehaug, E. (2015), "Introducing the concept of environmental policy integration into the discourse on sustainable tourism: a way to improve policy-making and implementation?", Journal of Sustainable Tourism, Vol. 23 No. 7, pp.977989.

ABEAR. (n.d.), "Panorama da Aviação Brasileira - Tarifas" available at: http://panorama.abear.com.br/dados-e-estatisticas/tarifas (accessed 23 September 2019).

Adams, S.-A. (2017), "Sustainable cruise ship employment for the Caribbean region - a conceptual perspective", Worldwide Hospitality and Tourism Themes, Vol. 9 No. 1, pp.60-69.

Albrecht, J.F., den Heyer, G. and Stanislas, P. (editors) (2019), Policing and Minority Communities: Contemporary Issues and Global Perspectives. Springer Nature, Switzerland.

Allis, T., Castro, R. and Fraga, C. (2017), "Airport concessions in Brazil and its influences on service quality: the cases of Brasília and São Paulo-Guarulhos airports", Journal of Spatial and Organizational Dynamics, Vol. 5 No. 4, pp.337-350.

ANAC. (n.d.). "Dados do Anuário do Transporte Aéreo", available at: www.anac.gov.br/assuntos/dados-e-estatisticas/mercado-de-transporte-aereo/anuario-dotransporte-aereo/dados-do-anuario-do-transporte-aereo (accessed 18 September 2019).

Angelini, A. (2020), "A Favela That Yields Fruit: Community-Based Tour Guides as Brokers in the Political Economy of Cultural Difference", Space and Culture, Vol 23 No. 1, pp.15-33. https://doi.org/10.1177/1206331219865694 
Araújo, L.M. de. and Dredge, D. (2012), "Tourism development, policy and planning in Brazil", Lohmann, G. and Dredge, D. (Eds), Tourism in Brazil: Environment, Management, and Segments, Routledge, London, pp.17-29.

Banco Central (2019), "Plano Real", available at: www.bcb.gov.br/controleinflacao/planoreal (accessed 18 August 2019).

Bandyopadhyay, R. and Nascimento, K. (2010), "Where fantasy becomes reality: how tourism forces made Brazil a sexual playground", Journal of Sustainable Tourism, Vol. 18 No. 8, pp.933-949.

Barreto, D. and Jensen, L.J. (2020), "Using cultural representations in video games to confront stereotypes and misconceptions about Brazil: Favelas, Futebol, and Brasilidade", Papa R. (ed), Handbook on Promoting Social Justice in Education, Springer, Cham, pp.1663-1684. https://doi.org/10.1007/978-3-030-14625-2_138

Bondarik, R., Pilatti, L.A. and Horst, D.J. (2020), "Sports mega-events and overestimated promises: the case of the 2014 FIFA World Cup in Brazil", Journal of Tourism and Cultural Change, Vol. 18 No. 3, pp.351-367. https://doi.org/10.1080/14766825.2020.1727488

Borrini-Feyerabend, G., Dudley, N., Jaeger, T., Lassen, B., Pathak Broome, N., Phillips, A. and Sandwith, T. (2013), Governance of Protected Areas: From understanding to action. Best Practice Protected Area Guidelines, IUCN, Gland, Switzerland.

Braga, M.A.C. and Bercovici, G. (2018), Produção Artesanal do Queijo de Leite Cru: Dilemas do desenvolvimento agrícola brasileiro. (PhD Thesis). Universidade de São Paulo, São Paulo.

Brasil (2016), Referencial de Combate à Fraude e à Corrupção: aplicável a órgãos e entidades da administração pública, Portal Tribunal de Contas da União, Brasília, DF, 2016.

Brooks, A. and Heaslip, V. (2019), "Sex trafficking and sex tourism in a globalised world", Tourism Review, Vol. 74 No. 5, pp.1104-1115.

Cai, L., Jafari, J., Scott, N., Niekerk, M. van and Martino, M. de. (Eds.) (2017), Knowledge Transfer to and within Tourism: Academic, Industry and Government Bridges. Emerald Publishing, Bradford.

Carnicelli-Filho, S. and Lohmann, G. (2012), "Tourism Development and Distribution Channels in Brotas: Brazilian Adventure Capital”, Lohmann, G. and Dredge, D. (Eds), Tourism in Brazil: Environment, Management and Segments, Routledge, London, pp.91-107. 
CLIA Brasil/FGV (2018), "Cruzeiros Marítimos Temporada 2017-2018", available at: https://abremar.com.br/wp-content/uploads/2018/10/CLIA v11.pdf (accessed 11 December 2019).

CLIA Brasil (2019), “Temporada 2019/2020 de Cruzeiros terá mais de 530 mil leitos ofertados", available at: https://abremar.com.br/temporada-20192020-de-cruzeiros-teramais-de-530-mil-leitos-ofertados (accessed 23 September 2019).

CLIA Brasil (n.d.), "Dados do Setor", available at: https://abremar.com.br/dados-do-setor (accessed 18 September 2019).

Darolt, M.R., Lamine, C., Brandenburg, A., Alencar, M. de C.F. and Abreu, L.S. (2016), "Alternative foods network and new production-consumption relations in France and Brazil", Environment \& Society, Vol. 19 No. 2, pp. 1-22.

de Miranda Mota, C.M. and de Figueiredo, C.J.J. (in press), "Identifying areas vulnerable to homicide using multiple criteria analysis and spatial analysis", Omega.

Duc Pham, T., Dwyer, L. and Spurr, R. (2009), "Constructing a Regional TSA: The Case of Queensland", Tourism Analysis, Vol. 13 No. 5/6, pp.445-460.

Fernandes, E. and Pacheco, R.R. (2018), "Managerial performance of airports in Brazil before and after concessions", Transportation Research Part A: Policy and Practice, Vol. 118, pp.245-257.

Forbes (2019), "Estudo traz Brasil como o segundo país mais perigoso para turistas mulheres", available at: https://forbes.com.br/forbeslife/2019/07/20-lugares-mais-perigosospara-turistas-mulheres (accessed 4 October 2019).

Femenia-Serra, F., Neuhofer, B. and Ivars-Baidal, J.A. (2019), "Towards a conceptualisation of smart tourists and their role within the smart destination scenario", The Service Industries Journal, Vol. 39 No. 2, pp.109-133.

Freire-Medeiros, B., Rocha, L. de M., Farias, J., \& Name, L. (2020), "Of cable-cars and helicopters: mobility regimes and the politics of visibility in the favelas of Rio de Janeiro", Visual Studies, Vol 35 No. 2-3, pp.1-11. https://doi.org/10.1080/1472586X.2020.1840099

Gomes, M.S. (2012), "A imagem do Brasil no exterior e o turismo: a operacionalização do Plano Aquarela em Portugal", Revista Rosa dos Ventos, Vol. 4 No. 4, pp.506-521. 
Holanda, S.B. de, (2010), Visão do Paraíso: Os motivos edênicos no descobrimento e colonização do Brasil, Companhia das Letras, São Paulo, SP.

Holanda, S. B. de (2015). Raízes do Brasil. Companhia das Letras, São Paulo, SP.

IBGE (2016), "Sistema de Contas Nacionais", available at: www.ibge.gov.br/estatisticas/economicas/industria/9052-sistema-de-contas-nacionaisbrasil.html?edicao=17895 (accessed 24 October 2019).

ICCA (2019), "ICCA releases largest ever statistics report for 2018", available at: www.iccaworld.org/newsarchives/archivedetails.cfm?id=935584 (accessed 8 September 2020).

ICMBio - Instituto Chico Mendes de Conservação da Biodiversidade (2020), "Monitoramento da visitação em Unidades de Conservação Federais: Resultados de 2019 e breve panorama histórico", available at: www.icmbio.gov.br/portal/images/stories/comunicacao/publicacoes/monitoramento visitaca o em ucs federais resultados 2019 breve panorama historico.pdf (accessed 13 July 2020).

IUCN (2020), Guidance for using the IUCN Global Standard for Nature-based Solutions. A user-friendly framework for the verification, design and scaling up of Nature-based Solutions, IUCN, Gland, Switzerland.

JLL's Hotels \& Hospitality Group (2019), Hotel Investment Outlook 2019, JLL's Hotels \& Hospitality Group, Sydney.

Jones, T., Wood, D., Hughes, M., Duc Pham, T., Pambudi, D., Spurr, R., Dwyer, L., Deery, M. and Fredline, L. (2010), Tourism Destination Modelling: Building a sustainable planning tool for Australian tourism destinations, Sustainable Tourism Cooperative Research Centre, Gold Coast, Qld.

Leung, Y.-F., Spenceley, A., Hvenegaard, G. and Buckley, R. (Eds.) (2018), Tourism and Visitor Management in Protected Areas: Guidelines for Sustainability. Best Practice Protected Area Guidelines, IUCN, Gland, Switzerland.

Lima, E., Maia, T.S.T., Lobosco, A. and Moraes, M.B. (2016), "Megaeventos esportivos frente a pequenos eventos: reflexões considerando-se a realidade brasileira recente", Podium Sport, Leisure and Tourism Review, Vol. 5 No. 3, pp.89-110. 
Lohmann, G. and Dredge, D. (2012), "Introduction”, Lohmann, G. and Dredge, D. (Eds), Tourism in Brazil: Environment, Management and Segments. Routledge, London and New York, pp.1-16.

Lohmann, G., Fraga, C. and Castro, R. (2013), Transportes e Destinos Turísticos: Planejamento e Gestão, Elsevier, Rio de Janeiro, RJ.

MacKendrick, N. (2014), “Foodscape”, Contexts, Vol. 13, pp.16-18.

Machado, B.V.Z., Ingouville, M., Damasceno, T.M., Salles, D.C. and Albuquerque, C.T.V. (2019), "A Evolução recente do Modelo de Concessão Aeroportuária sob a Ótica da Financiabilidade", BNDES Setorial, Vol. 25 No. 50, pp.60-65.

Manso, B.P. (2020), A República das Milícias. Todavia, São Paulo.

Marques, N.L., Brandão, L.E.T. and Gomes, L.L. (2019), "The Rio de Janeiro international airport privatisation: a problem of overbidding?", Latin American Business Review, Vol. 20 No. 3, pp.249-268.

Marques, R.B., Alves, C.A. and Wada, E.K. (2020), "Turismo e corrupção no Brasil: uma perspectiva política e econômica", Turismo em Análise, Vol. 31 No. 1, pp.1-18.

Mascarenhas, R.G.T. and Gândara, J.M.G. (2015), "O papel da gastronomia na qualidade e na competitividade dos destinos turísticos", CULTUR: Revista de Cultura e Turismo, Vol. 9 No. 1 , pp.60-83.

Mataruna-dos-Santos, L. J. (2020), "The Intentions of international tourists to attend the 2016 Rio summer Olympic and Paralympic games: A study of the image of Rio de Janeiro and Brazil", Annals of Applied Sport Science, Vol. 8 No. 3, pp.1-10. https://doi.org/10.29252/aassjournal.798

Minc, A. (1994). A Nova Idade Média. Ática, São Paulo.

Ministério do Meio Ambiente (2019), "Cadastro Nacional de Unidades de Conservação", available at: www.mma.gov.br/areas-protegidas/cadastro-nacional-de-ucs (accessed 25 September 2019).

Ministério do Turismo (2003), Plano Nacional do Turismo 2003 - 2007: Diretrizes, Metas e Programas, Ministério do Turismo, Brasília, DF. 
Ministério do Turismo (2018a), "Estudo da Demanda Turística Internacional", available at: www.dadosefatos.turismo.gov.br/2016-02-04-11-54-03/demanda-tur\%C3\%ADsticainternacional.html (accessed 18 August 2019).

Ministério do Turismo (2018b). Plano Nacional de Turismo 2018-2022. Brasília: Ministério do Turismo.

Ministério do Turismo (2019a), "Estudo de Demanda Turística Nacional 2012 e Anuário Estatístico 2019", available at: www.dadosefatos.turismo.gov.br/dadosefatos/home.html (accessed 18 August 2019).

Ministério do Turismo (2019b), "Boletim de Estatísticas Turísticas - 2019", available at: www.dadosefatos.turismo.gov.br/boletins.html (accessed 9 September 2019).

Ngo, T., Lohmann, G. and Hales, R. (2018), "Collaborative marketing for the sustainable development of community-based tourism enterprises: voices from the field", Journal of Sustainable Tourism, Vol. 26 No. 8, pp.1325-1343.

Ngo, T., Hales, R. and Lohmann, G. (2019), "Collaborative marketing for the sustainable development of community-based tourism enterprises: a reconciliation of diverse perspectives", Current Issues in Tourism, Vol. 22 No. 18, pp.2266-2283.

Oliveira, R.P., Oliveira, A.V., Lohmann, G. and Bettini, H.F. (2020), "The geographic concentrations of air traffic and economic development: A spatiotemporal analysis of their association and decoupling in Brazil", Journal of Transport Geography, Vol. 87.

Pan, B. and Yang, Y. (2017), "Monitoring and forecasting tourist activities with big data", Uysal, M., Schwartz, Z. and Sirakaya-Turk, E. (Eds), Management Science in Hospitality and Tourism: Theory, practice, and applications, Apple Academic Press, Palm Bay, pp.43-62.

Pan, S.L. and Zhang, S. (2020), "From fighting COVID-19 pandemic to tackling sustainable development goals: An opportunity for responsible information systems research", International Journal of Information Management, Vol 55.

Pereira Neto, C., Casagrande, P., Lancieri, F. and Moraes, J. (2016), "Pro-competition rules in airport privatization: international experience and the Brazilian case", Journal of Air Transport Management, Vol. 54, pp.9-16.

Perinotto, A.R.C., Soares, D.B., Soares, J.R.R. (2020), "Websites oficiais como promoção turística: um estudo comparativo entre Brasil, França e Holanda à luz do marketing digital", 
Turismo: Estudos \& Práticas (UERN), Mossoró/RN, Vol. 9 No. 2, 1-28. http://natal.uern.br/periodicos/index.php/RTEP/index [ISSN 2316-1493].

Pino, G. and Peluso, A.M. (2018), "The development of cruise tourism in emerging destinations: evidence from Salento, Italy", Tourism and Hospitality Research, Vol. 18 No. 1, pp.15-27.

Queiroz Neto, A., Lohmann, G., Scott, N. and Dimmock, K. (2017), "Rethinking competitiveness: important attributes for a successful scuba diving destination", Tourism Recreation Research, Vol. 42 No. 3, pp.356-366.

Rabahy, W.A. (2020), "Tourism analysis and perspectives in Brazil", Revista Brasileira de Pesquisa em Turismo, Vol. 14 No. 1, pp.1-13.

Ruiz-Real, J.L., Uribe-Toril, J. and Gázquez-Abad, J.C. (2020), “Destination branding: Opportunities and new challenges", Journal of Destination Marketing \& Management, Vol. 17.

Santos, G.E. de O. (2017), "Conta Satélite do Turismo do Brasil: Novas estimativas", Annals of the $14^{\text {th }}$ Seminário da Associação Nacional de Pesquisa e Pós-Graduação em Turismo, ANPTUR, Balneário Camoboriú.

Santos, G.E. de O., Gursoy, D., Ribeiro, M.A. and Netto, A.P. (2019), "Impact of transparency and corruption on mega-event support", Event Management, Vol. 23, pp.27-40.

Schallhorn, C. (2020), "Samba, sun and social issues: How the 2014 FIFA World Cup and the 2016 Rio Olympics changed perceptions of Germans about Brazil", International Review for the Sociology of Sport, Vol. 55 No. 5, pp.603-622.

Schiefelbusch, M., Jain, A., Schäfer, T. and Müller, D. (2007), "Transport and tourism: roadmap to integrated planning developing and accessing integrated travel chains", Journal of Transport Geography, Vol. 15 No. 2, pp.94-103.

Souza, T. do V.S.N., Thapa, B., Rodrigues, C.G. de O. and Imori, D. (2019), "Economic impacts of tourism in protected areas of Brazil", Journal of Sustainable Tourism, Vol. 27 No. 6, pp.735-749.

Thomaz, G., Biz, A., Bettoni, E., Mendes-Filho, L. and Buhalis, D. (2017), "Content mining framework in social media: A FIFA world cup 2014 case analysis", Information and Management Vol 54, pp.786-801. http://dx.doi.org/10.1016/j.im.2016.11.005 
Transparência Internacional (2019), "Índice de Percepção da Corrupção 2018”, available at: https://ipc2018.transparenciainternacional.org.br (accessed 13 September 2019).

Trentin, F. (2016), "Governança turística em destinos brasileiros: comparação entre Armação dos Búzios/RJ, Paraty/RJ e Bonito/MS", Pasos - Revista de Turismo y Patrimonio Cultural, Vol. 14 No. 3, pp.645-658.

Trigo, L.G.G. (2003), “The old problems of Brazilian tourism”, Tourism Review, Vol. 58 No. 1, pp.19-24.

Trigo, L.G.G. (2020), "Viagens e turismo: dos cenários imaginados às realidades disruptivas", Revista Brasileira de Pesquisa em Turismo, Vol. 14 No. 3, pp.1-13.

Ubrafe (2019), "Impacto e resultados dos eventos com foco em geração de negócios no Estado de São Paulo", available at: https://ubrafe.org.br/download/ubrafeimpactoeventosfinal.pdf (accessed 9 September 2020).

Valente, F., Dredge, D. and Lohmann, G. (2014), "Leadership capacity in two Brazilian regional tourism organisations", Tourism Review, Vol. 69 No. 1, pp.10-24.

Valente, F., Dredge, D. and Lohmann, G. (2015), "Leadership and governance in regional tourism", Journal of Destination Marketing \& Management, Vol 4 No. 2, pp.127-136.

Vernon, J., Essex, S., Pinder, D., and Curry, K. (2005), "Collaborative policymaking: local Sustainable Projects", Annals of Tourism Research, Vol 32 No. 2, pp.325-345.

Vizcaino-Suárez, L.P. and Díaz-Carrión, I.A. (2019), "Gender in tourism research: perspectives from Latin America”, Tourism Review, Vol. 74 No. 5, pp. 1091-1103. https://doi.org/10.1108/TR-02-2017-0021

Visual Capitalist (2020), "How the 20 largest economies stack up", available at: www.visualcapitalist.com/countries-reliant-tourism (accessed 7 December 2020).

World Bank (2015), World Development Indicators 2015, The World Bank, Washington, DC.

WHO (2020), World Health Organization Coronavirus Disease (COVID-19) Dashboard, available at: https://covid19.who.int/ (accessed 21 December 2020).

World Tourism Organization (2012), Global Report on Food Tourism, World Tourism Organization, Madrid. 


\section{Author biography and contribution}

\section{Gui Lohmann}

Griffith University, Australia

\section{g.lohmann@griffith.edu.au}

Biography: Dr Gui Lohmann is Professor in Air Transport and Tourism Management at Griffith University (Australia). He has co-edited the book Tourism in Brazil: Environment, Management and Segments. Professor Lohmann is also one of the founders of ABRATUR.

Contribution: As the first author, lead the writing of the paper, as well as the structure and coordination of the work amongst all the co-authors. Also directly contributed to the two sections on air transport and cruise tourism.

\section{Heros Augusto Santos Lobo}

Federal University of São Carlos, Brazil

\section{heroslobo@ufscar.br}

Biography: Dr. Lobo is Professor at Department of Geography, Tourism and Humanities at Federal University of São Carlos (UFSCar). PhD in Geosciences and Environment. Member of the Board of Directors of International Show Caves Association (ISCA). Member of the International Academy for the Development of Tourism Research in Brazil (ABRATUR).

Contribution: Participated in the design, coordination and review of the article. Contributed directly in the sections: Parks and Conservation Areas, Recommendations for the future frontier and Final Remarks.

\section{Luiz Gonzaga Godoi Trigo}

Universidade de São Paulo, Brazil

\section{trigo@usp.br}

Biography: Full Professor in Leisure and Tourism at School of Arts, Sciences and Humanities $(E A C H)$ at the University of São Paulo (USP, Brazil). He graduated in philosophy and tourism, 
and has a PhD in Education. He has written 21 books, several book chapters, journal articles about tourism, culture, education and entertainment.

Contribution: Wrote several sections of the paper, including those about business tourism, management and education in Brazil.

\section{Vander Valduga}

Federal University of Paraná, Brazil

\section{vandervalduga@gmail.com}

Biography: Professor of Tourism at the Federal University of Paraná (Brazil). His research interests include the geography of food and beverages, wine tourism and spatial relations in hospitality and tourism.

Contribution: He was responsible for writing the sections about gastronomy and corruption, collecting relevant data and critically reviewing the final version of the paper.

\section{Rafael Castro}

CEFET/RJ, Petrópolis, Brazil

\section{rafael.teixeira@cefet-ri.br}

Biography: Adjunct Professor at the Department of Tourism at the Federal Center for Technological Education Celso Suckow da Fonseca (CEFET/RJ); PhD and MSc in Transport Engineering at the Federal University of Rio de Janeiro; Bachelor's degree in Tourism Management (Positivo University)

Contribution: Co-writing the air transport and cruise tourism sections, undertaking secondary data collection, data analysis and interpretation, drafting the article.

\section{Mariana de Freitas Coelho}

Federal University of Viçosa, Brazil 


\section{marifcoelho@gmail.com}

Biography: Marketing Professor at the Federal University of Viçosa (Brazil). PhD in Business from the Federal University of Minas Gerais. Dr Coelho coordinates Mercademia, a Business Management Research Group. Her research expertise include consumer experience, destination marketing and tourist behavior

Contribution: Drafting and critical revision of the article.

\section{Marina Wöhlke Cyrillo}

Instituto Federal de Educação, Ciência e Tecnologia do Rio Grande do Sul

\section{Marina.cyrillo@poa.ifrs.edu.br}

Biography: Ms Cyrillo has a Master's degree in Tourism and Hospitality from the University of the Vale of Itajaí (Brazil). She teaches at the Federal Institute of Education, Science and Technology of Rio Grande do Sul, in Porto Alegre.

Contribution: She contributed to the design of the work, data analysis and interpretation, particularly the parts about accommodation and the MICE segment, also drafting and critically reviewing the article.

\section{Yoná Dalonso}

University of the Region of Joinville, Brazil

yona.dalonso@univille.br

Biography: Master's degree in Communication Sciences (University of São Paulo, USP) and $\mathrm{PhD}$ in Geography (Minho University, Portugal). Full professor at the University of the Region of Joinville (Univille). Member of the International Academy for the Development of Tourism Research in Brazil (ABRATUR).

Contribution: Contributed to the gastronomy and MICE sections, collecting and interpreting data. Provided a critical review of the paper. 


\section{Maria Henriqueta Gimenes-Minasse}

Universidade Anhembi Morumbi

\section{mariegimenes@gmail.com}

Biography: Full Professor of Gastronomy and Hospitality at Anhembi Morumbi University (São Paulo, Brazil). She holds a Masters in Sociology and a PhD degree in Food History. She is a member of the International Academy for the Development of Tourism Research in Brazil (ABRATUR). Her research interests include food \& beverage management, food \& tourism, hospitality and commensality.

Contribution: Data collection, data analysis and interpretation, drafting and critical revision of Gastronomy section.

\section{Marlusa de Sevilha Gosling}

Federal University of Minas Gerais, Brazil

\section{mg.ufmg@gmail.com}

Biography: Associate Professor of Marketing at the Federal University of Minas Gerais (Brazil), holding a PhD in Management from the same institution. She is the Editor-in-Chief of the journal Marketing \& Tourism Review. She is a visiting lecturer at the University of Algarve, Portugal. Her research expertise is in tourism, marketing and strategic management.

Contribution: Drafting and critical revision of the article.

\section{Ricardo Lanzarini}

Federal University of Rio Grande do Norte, Brazil

\section{ricardolanzarini@ccsa.ufrn.br}

Biography: Bachelor's degree in Tourism and PhD in Human Sciences. Assistant Professor at the Department of Tourism at the Federal University Rio Grande do Norte (UFRN).

Contribution: Writing of the section about gender, sexual tourism and minorities. 


\section{Sergio Rodrigues Leal}

Federal University of Pernambuco, Brazil

\section{sergio.rleal@ufpe.br}

Biography: Associate Professor and Head of the Postgraduate Programme in Hotel Management and Tourism at the Federal University of Pernambuco (Brazil). He holds a Ph.D. in Tourism (University of Surrey, UK) and a Master of Tourism (James Cook University, Australia). His research focuses on tourism education and tourism emerging issues.

Contribution: Data analysis and interpretation. Section on education related to tourism. Drafted the article and provided critical revision.

\section{Osiris Marques}

Federal Fluminense University, Rio de Janeiro, Brazil

\section{osirismarques@id.uff.br}

Biography: Associate Professor at the School of Tourism and Hospitality, Fluminense Federal University (Brazil). He holds a PhD in Economics from the Economics Institute of the Federal University of Rio de Janeiro/Brazil (UFRJ). His current research interests involve topics concerning tourism behavioural economics and tourism economics.

Contribution: Co-written the section on Economy, undertaking data collection; analysis and interpretation. She also drafted the article.

\section{Verônica Feder Mayer}

Federal Fluminense University, Rio de Janeiro, Brazil

\section{veronicamayer@id.uff.br}

Biography: Associate Professor at the School of Tourism and Hospitality, Fluminense Federal University (Brazil). She holds a PhD in Business from the COPPEAD Graduate School 
of Business of the Federal University of Rio de Janeiro. Her research interests are consumer behaviour, behavioural economics and well-being in tourism.

Contribution: Co-written the section on Economy, undertaking data collection; analysis and interpretation. She also drafted the article.

Jasmine Cardozo Moreira

Ponta Grossa State University, Brazil

jasmine@uepg.br

Biography: Dr Moreira is Professor in Tourism at Ponta Grossa State University (Brazil). She is the Head of LABTAN, the University laboratory that focuses on tourism in protected areas. Her expertise is on tourism planning in Geoparks and National Parks.

Contribution: Data collection and Data analysis and interpretation.

\title{
Lauro Almeida de Moraes
}

Federal University of Paraná, Brazil

lauromoraes@ufpr.br

Biography: PhD in Geography and Master in Culture and Tourism, with 15 years' experience as a journalist. As a reporter, Dr Moraes has written to the leading press agencies in Brazil (Rede Globo and O Estado de São Paulo)

Contribution: Contributed to the collection, analysis, data review and writing about corruption.

\author{
Alexandre Panosso Netto \\ University of São Paulo, Brazil \\ panosso@usp.br
}


Biography: Professor at the School of Arts, Sciences and Humanities (EACH) at the University of São Paulo (Brazil) since 2006. He has published 24 books and more than 50 papers. His expertise is in the field of higher education in tourism, tourism experience, tourism epistemology, tourism theories and tourism planning.

Contribution: Data analysis and interpretation. Section on education related to tourism.

\section{André Riani Costa Perinotto}

Federal University of Piauí \& Ceará State University, Brazil

perinotto@ufpi.edu.br

Biography: Professor of the Tourism Program at the Federal University of Delta do Parnaíba (Parnaíba) and Visiting Professor of the Master in Tourism Business Management at Ceará Estate University (Fortaleza).

Contribution: Contribution to the competitiveness section, in addition to the information about MICE. Overall reading and writing of the paper.

\section{Ambrozio Queiroz Neto}

CEFET-RJ Uned Nova Friburgo, Brazil

\section{ambrozio.neto@cefet-ri.br}

Biography: Associate Professor at the Department of Tourism at the Federal Center for Technological Education Celso Suckow da Fonseca (CEFET/RJ, Brazil). He holds a PhD in Tourism Management from Griffith University (Australia) and a Master's degree in Technology from CEFET/RJ.

Contribution: Co-writing the competitiveness section, undertaking secondary data collection, data analysis and interpretation.

\section{Fabia Trentin}

Federal Fluminense University, Brazil 


\section{ftrentin@id.uff.br}

Biography: Associate Professor in the Faculty of Tourism and Hospitality at the Federal Fluminense University. She currently leads the Policy, Governance and Tourism Laboratory (LabPGTUR). She has a PhD in Tourism, Leisure and Culture from the University of Coimbra (Portugal). Dr Trentin has research interests in public policies and governance in tourism.

Contribution: She wrote the sections about tourism policy and planning, collecting secondary data to support the paper.

\section{Sidnei Raimundo}

University of São Paulo

\section{sraimundo@usp.br}

Biography: Associate Professor at the School of Arts, Sciences and Humanities (EACH) at the University of São Paulo (Brazil). He holds a bachelor's degree, Masters and Ph.D. in Geography. He has experience in protected areas, urban parks, and other outdoor spaces, researching the impacts of recreation and tourism.

Contribution: data analysis and interpretations; drafting the article, critical vision of the article 